Jurnal Indonesia Sosial Teknologi: p-ISSN: 2723 - 6609

e-ISSN : 2745-5254

Vol. 2, No. 6 Juni 2021

\title{
ANALISA KEGAGALAN PASCA WELDING REPAIR PADA CRANKSHAFT KOMPRESOR
}

\section{Zendi Zakaria, D. N Adnyana}

Magister Mechanical Engineering Department of Mechanical Engineering

Faculty of Industrial Technology Institut Sains dan Teknologi Jakarta (ISTN)

Email: Zendizakaria20@gmail.com, adnyanadn@yahoo.com

\section{Abstract}

The failure analysis performed on the compressor crankshaft after welding repairs aims to determine the cause of post-weld repair failure and the strength value of the crankshaft material. This compressor is a single acting reciprocating type using 3 stages, this compressor fails when the operation reaches 3298 hours with a maximum pressure of 330 bar. A number of specimens were taken from the broken compressor crankshaft after welding repair for inspection including visual inspection, macrostructure, chemical analysis, microstructure and hardness inspection. From the results of the analysis of the condition of the initial location of the surface from an angle perpendicular to the shaft diameter of $30 \mathrm{~mm}$, the results of the analysis of the chemical composition of the nodular cast iron crankshaft material SAE J434, the results of metallographic testing are ferrite, pearlite and nodular graphite structures and the results of the hardness test are the largest 682 $\mathrm{HV}$ and the lowest is $110 \mathrm{HV}$. The results of the failure analysis showed that the crankshaft experienced brittle fracture caused by the welding of the crankshaft connection using $\mathrm{CuNi}$ material, showing poor quality considering the melting point of cast iron material with CuNi welding material so that it could not blend properly and there was solidification cracking during welding and other factors. which may be a supporter of failure, namely periodic maintenance that is not carried out properly and is also supported by a high-pressure compressor type so that the load received by the compressor crankshaft is quite high.

Keyword: Failure analysis; Crankshaft; Welding; brittle fracture; periodic maintenance, solidification cracking.

\footnotetext{
Abstrak

Analisa kegagalan yang dilakukan pada crankshaft kompresor pasca welding repair tujuan penelitian ini untuk mengetahui penyebab kegagalan pasca welding repair dan nilai kekuatan pada material crankshaft. Kompresor ini termasuk jenis reciprocating single acting dengan menggunakan 3 Stage, kompresor ini terjadi kegagalan saat jam operasi mencapai 3298 jam dengan tekanan maksimum 330 bar. Sejumlah spesimen diambil crankshaft kompresor yang patah pasca welding repair untuk dilakukan pemeriksaan meliputi pemeriksaan visual, makrostuktur, analisa kimia, pemeriksaan struktumikro dan kekerasan. Dari hasil analisa makro kondisi lokasi awal permukaan berasal dari sudut tegak lurus terhadap poros diameter 30 mm, hasil analisa komposisi kimia material crankshaft besi cor nodular SAE J434,
} 
hasil pengujian metalografi terdapat struktur ferit, perlit dan grafit nodular dan hasil pengujian kekerasan yang terbesar $682 \mathrm{HV}$ dan yang terendah $110 \mathrm{HV}$. Hasil analisa kegagalan menunjukkan bahwa crankshaft mengalami patah getas yang disebabkan oleh penyambungan crankshaft pengelasan menggunakan material $\mathrm{CuNi}$ menunujukkan mutu yang kurang bagus mengingat titik cair material besi cor dengan material las $\mathrm{CuNi}$ berbeda sehingga tidak dapat menyatu dengan baik serta terdapat solidification cracking pada saat proses pengelasan dan Faktor lain yang mungkin menjadi pendukung terjadi kegagalan yaitu perawatan berkala yang tidak terlaksana dengan baik dan juga didukung dengan jenis kompresor bertekanan tinggi sehingga beban yang diterima oleh crankshaft kompresor cukup tinggi.

Kata kunci: Analisa kegagalan; Crankshaft; Welding; patah getas; perawatan berkala, solidification cracking.

\section{Pendahuluan}

Penelitian ini membahas tentang analisa kegagalan pasca welding repair pada crankshaft kompresor reciprocating. Kompresor adalah alat mekanik yang berfungsi untuk meningkatkan tekanan fluida yang mampu memampatkan gas atau udara. Dalam kaitannya jenis kompresor yang digunakan haruslah sesuai dengan keperluan dan penempatannya dalam suatu proses (Adnyana, n.d., 2021). Salah satu alat yang digunakan dalam penelitian ini adalah kompresor reciprocating single acting. Dalam kompresor ada beberapa komponen salah satunya Poros penghubung (crankshaft) yang mengalami kegagalan pasca welding repair komponen ini tidak luput juga dari kerusakan selama pemakaiannya. Penyebab kegagalan mesin dalam bentuk yang paling sederhana, kegagalan dapat didefinisikan sebagai setiap perubahan pada bagian mesin atau komponen yang menyebabkannya tidak dapat menjalankan fungsi yang diinginkan memuaskan. Tahapan umum sebelum kegagalan akhir adalah kegagalan yang baru jadi kerusakan yang baru terjadi kesusahan kerusakan dan kerusakan semuanya akhirnya membuat bagian atau komponen tersebut tidak dapat diandalkan atau tidak aman untuk digunakan secara berkelanjutan (Bloch, H. P, 2010). Oleh karena itu dilakukan repair welding untuk sebagai prosedur logis yang memastikan produksi komponen bisa

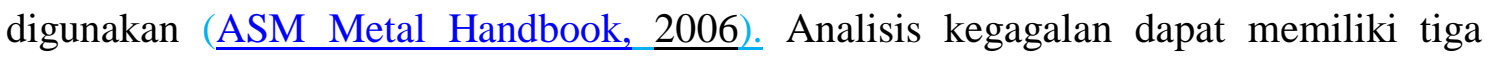
tujuan luas yaitu menentukan mode, penyebab, atau akar penyebab. Dalam ini kasus harus menentukan penyebab kegagalan untuk mencegah kejadian di masa depan, dan / atau meningkatkan kinerja perangkat, komponen atau struktur. Dimungkinkan untuk fatigue fracture sebagai akibat dari kegagalan berganda mekanisme atau root cause (Ferbrianti, 2016)

Analisis kegagalan dapat memberikan informasi untuk mengidentifikasi root cause yang tepat dari kegagalan. Makalah ini menyajikan analisis kegagalan setelah dilakukan repair welding terjadi kerusakan patah crankshaft oleh karena itu dilakukan pengecekan melalui laboratorium untuk mengetahui penyebab kegagalan pasca welding repair. 
Dengan jam operasi 3298 jam tekanan maksimum kompresor 330 bar dengan rata-rata running hours 6 jam/hari dengan tekanan rata-rata 250 bar suhu filter inlet $\pm 35^{\circ} \mathrm{C}$ terjadi kegagalan pertama patah pada crankshaft berbahan material besi cor nodular dengan banyaknya kebutuhan angin bertekanan untuk produksi sehingga memutuskan crankshaft dilakukan repair welding dengan dua metode pengelasan yaitu las listrik titik las berfungsi untuk mengunci posisi center sebelum dilakukan pengelasan utama yaitu oxyfuel gas welding dengan logam pengisi $\mathrm{CuNi}$. Setelah selesai di proses repair welding dipasang kembali untuk di operasikan kompresornya kurang dari 1 menit, crankshaft patah kembali diperkirakan bahwa ada kesalahan pada saat dilakukan repair welding. Tujuan dari analisa kegagalan ini adalah untuk memverifikasi material yang digunakan crankshaft apakah sudah memenuhi spesifikasi untuk digunakan, dan untuk bertujuan menetapkan jenis, penyebab kegagalan sehingga dapat menentukan tindakan perawatan atau perbaikan untuk mencegah kegagalan yang serupa dimasa yang akan datang.

\section{Metode Penelitian}

Dalam analisis kegagalan patahnya crankshaft pasca welding repair kompresor merupakan kejadian abnormal dikarenakan dari riwayat mesin kompresor tersebut ini adalah pertama kalinya yang terjadi. Pada gambar 1 terlihat ada beberapa komponen kompresor pada penelitian ini berfokus kepada komponen kompresor yaitu crankshaft yang patah pasca welding repair.

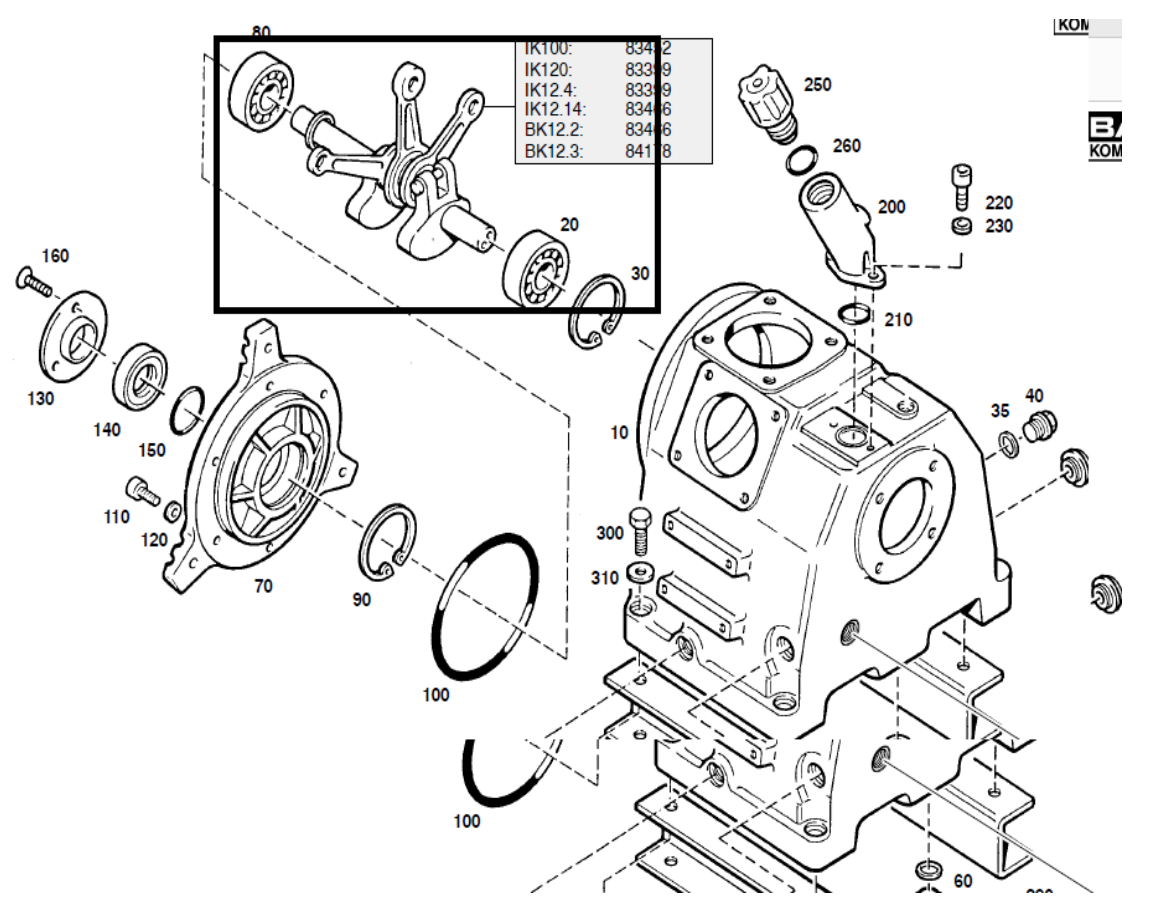

Gambar 1. Block machine (Handbook manual compressor, 2017)

Crankshaft yang patah ambil 2 bagian, bagian A yang didaerah pengelasan yang mengalami patahan dan bagian B yang jauh dari daerah patahan dan juga dari daerah pengelasan sebagai pembanding antara patahan bagian A untuk itu maka dilakukan pemeriksaan laboratorium. Patahan pada bagian A menunjukan permukaan jenis patah 
getas dan permukaanya halus pada sisi patahan. Untuk pengujian analisis kimia dilakukan menggunakan optical spectrometer tujuan pengujian analisis kimia adalah untuk menentukan bahan yang digunakan crankshaft apakah sudah sesuai spesifikasi.

Selain itu dilakukan pemeriksaan metalografi pada sampel yang disiapkan menggunakan optical mikroskop pada berbagai pembesaran. Metalografi sampe dipasang menggunakan resin lalu dipoles hingga rata dan dietsa. Menggunakan 2 metode etsa yang pertama adalah asam nitrat dan alkohol (Nital 2\%) yang kedua adalah kalium dikromat $\left(\mathrm{K}_{2} \mathrm{Cr}_{2} \mathrm{O}_{7}\right)$ untuk material berbahan $\mathrm{Cu}$ (tembaga)[12]. Untuk pengujian kekerasan dilakukan menggunakan sampel metalografi dengan metode Vickers pada beban $5 \mathrm{~kg}$. Pada pengujian fraktografi untuk melihat permukaan patahan dengan menggunakan alat camera digital dengan pembesaran $5 \mathrm{x}$.

Dari diagram alir dibawah ini kita mulai untuk melakukan identifikasi permasalahannya, menyusun rumusan masalah agar lebih terperinci, observasi lapangan dan pengumupulan data pendukung. 


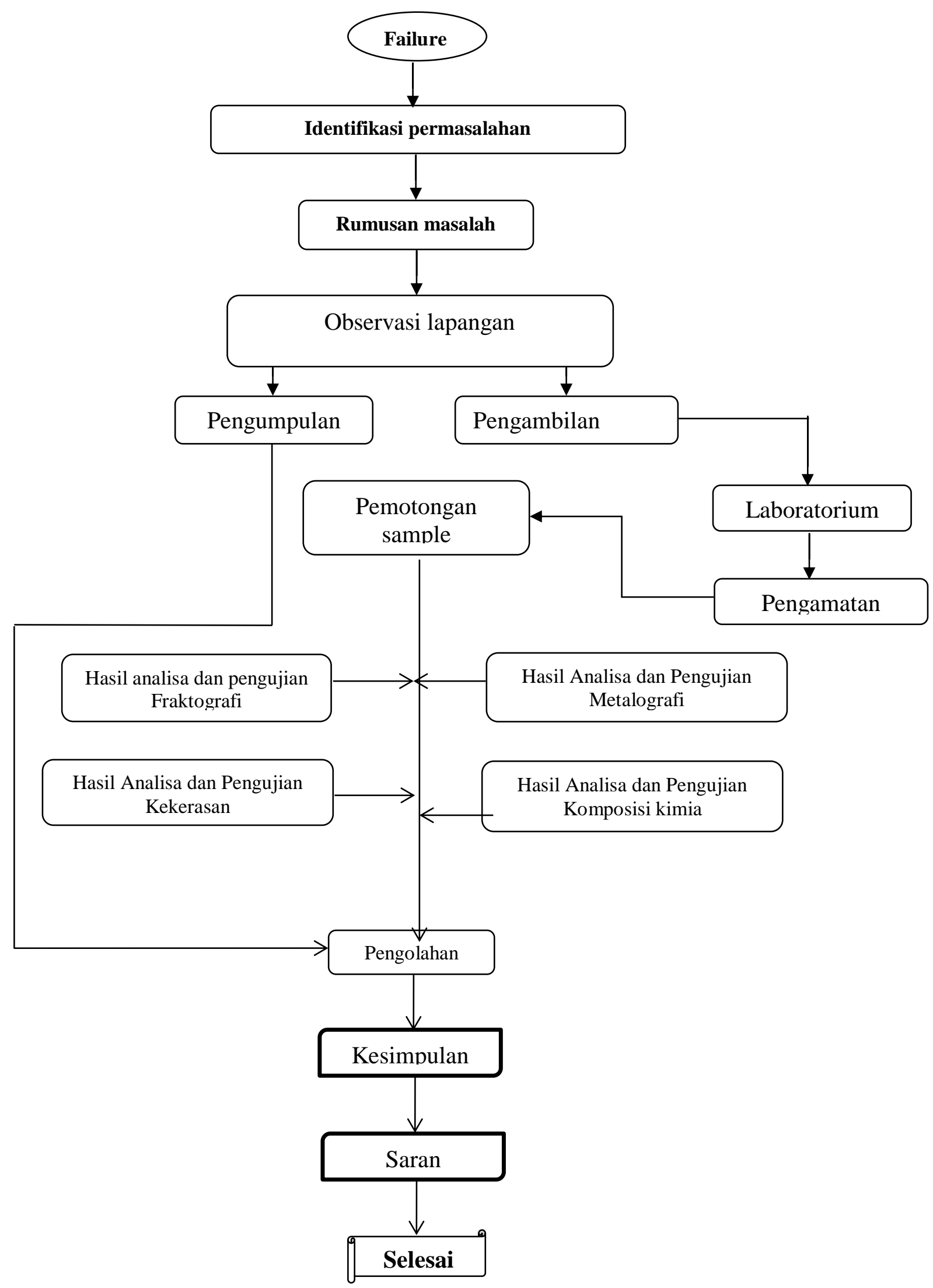

Diagram 1. Alur penelitianAnalisa Kegagalan Pasca Welding Repair Crankshaft Pada Compressor. 


\section{Hasil dan Pembahasan}

\section{Riwayat perawatan}

Riwayat perawatan berkala kompresor pada tanggal 20 maret 2017 dilakukan commissioning untuk hasilnya ok tidak ada masalah yang artinya bahwa kompresor ini sudah siap dioperasikan. Dengan desain kompresor seperti ini memungkinkan untuk hidup lebih lama yang berlangsung minimal 30.000 jam untuk perawatan juga simpel dan menghemat waktu pemeliharaan. Untuk standar perawatan berkala yang mengacu manual book 500 jam, 1000 jam, 2000 dan 4000 jam untuk histori perawatan berkala lihat ditabel 1 (Bauer, 2017). Salah satu penyebab terjadi kegagalan adalah tidak menjalakan dengan baik perawatan berkala menjadi salah satu faktor pendukung kegagalan.

Tabel 1. Riwayat servis berkala

\begin{tabular}{|c|c|c|c|c|c|}
\hline Tanggal & Jam Actual & $\begin{array}{c}\text { Std. } \\
\text { Perawatan } \\
\text { satuan jam }\end{array}$ & $\begin{array}{c}\text { Jenis } \\
\text { perawatan } \\
\text { yang } \\
\text { dilakukan }\end{array}$ & Keterangan & $\begin{array}{c}\text { Standar } \\
\text { manual book }\end{array}$ \\
\hline $\begin{array}{c}\text { 20-mar- } \\
2017\end{array}$ & 0 hours & & & $\mathrm{OK}$ & $\mathrm{OK}$ \\
\hline $\begin{array}{l}\text { 08-Jun- } \\
2017\end{array}$ & 510 hours & 500 hours & Intake Filter & Diganti & Diganti \\
\hline 03-Okt-17 & $\begin{array}{l}1050 \\
\text { hours }\end{array}$ & 1000 hours & Intake Filter & Dibersihkan & Diganti \\
\hline $\begin{array}{c}6 \text { febuari } \\
2018\end{array}$ & $\begin{array}{c}1457 \\
\text { hours }\end{array}$ & 1500 Hours & Intake Filter & Diganti & Diganti \\
\hline $\begin{array}{c}6 \text { febuari } \\
2018\end{array}$ & $\begin{array}{l}1457 \\
\text { hours }\end{array}$ & & $\begin{array}{c}\text { Penambahan } \\
\text { oli }\end{array}$ & $\begin{array}{c}\text { Penambahan } \\
\text { oli diatas }\end{array}$ & $\begin{array}{c}\text { Diatas } \\
\text { standar } \\
\text { minimum }\end{array}$ \\
\hline 05-Jun-18 & $\begin{array}{l}2023 \\
\text { hours }\end{array}$ & 2000 hours & Intake Filter & Diganti & Diganti \\
\hline 05-Jun-18 & $\begin{array}{l}2023 \\
\text { hours }\end{array}$ & 2000 hours & Pergantian oli & Diganti & Dikuras \\
\hline 22-Jun-18 & $\begin{array}{l}2079 \\
\text { hours }\end{array}$ & - & $\begin{array}{c}\text { Pengecekan } \\
\text { Libur } \\
\text { panjang }\end{array}$ & pengecekan & $\mathrm{OK}$ \\
\hline 10-Okt-18 & $\begin{array}{l}2503 \\
\text { hours }\end{array}$ & 2500 hours & Intake Filter & Dibersihkan & Diganti \\
\hline 10-Okt-18 & $\begin{array}{l}2503 \\
\text { hours }\end{array}$ & 4000 hours & $\begin{array}{c}\text { Penambahan } \\
\text { oli }\end{array}$ & $\begin{array}{c}\text { Penambahan } \\
\text { oli }\end{array}$ & $\begin{array}{l}\text { Standar } \\
\text { diatas } \\
\text { minimal }\end{array}$ \\
\hline 23-Jan-18 & $\begin{array}{l}2940 \\
\text { hours }\end{array}$ & 3000 hours & Intake Filter & Dibersihkan & Dibersihkan \\
\hline
\end{tabular}




\begin{tabular}{ccccc}
\hline 23-Jan-19 & $\begin{array}{c}2940 \\
\text { hours }\end{array}$ & 4000 hours & Pergantian oli & Tidak ada \\
pengecekan & $\begin{array}{c}\text { Harusnya } \\
\text { ditambahkan }\end{array}$ \\
\hline 19-Mei-19 & 3298 & & Crankshaft & \\
& hours & & patah & \\
\hline
\end{tabular}

\section{Pengamatan visual dan makro}

Dari hasil pengamatan (lihat gambar 2a) lokasi awal patah pada crankshaft berasal dari sudut tegaklurus terhadap poros $\varnothing \mathrm{D} 30 \mathrm{~mm}$, selain itu patahan sangat jelas (lihat gambar 3c) alur patahan intial crack berawal dari bawah yang menuju atas residual fracture, terlihat juga welding repair $\mathrm{CuNi}$ kurang baik ada beberapa rongga terlihat dan juga patahan tidak rata terlihat bergelombang, permukaan patahan crankshaft mempunyai bentuk patah getas yang dimulai dari bagian sudut (Gambar 2a), mengingat permukaan patahan telah dilakukan penggrindaan dan pengelasan maka tidak terlihat jelas namun masih terlihat dari alur atau radial mark yang dimulai dari permukaan halus menuju permukaan kasar (Gambar 2c) penyambungan crankshaft yang patah dengan pengelasan menggunakan jenis las material $\mathrm{CuNi}$ atau kuningan menunjukkan mutu yang kurang bagus mengingat tiik cair material besi cor kelabu dengan material las kuningan berbeda sehingga tidak menyatu dengan baik. Dan dilihat dari permukaan poros tersebut banyak ditemukan cacat guratan melingkar akibat gesekan dengan bearing sehingga putaran crankshaft tidak normal (Gambar 2b), dengan adanya cacat permukaan pada poros tersebut diduga pelumasan tidak normal atau kondisi pelumas kotor, sehingga putaran atau bekerjanya piston terganggu.

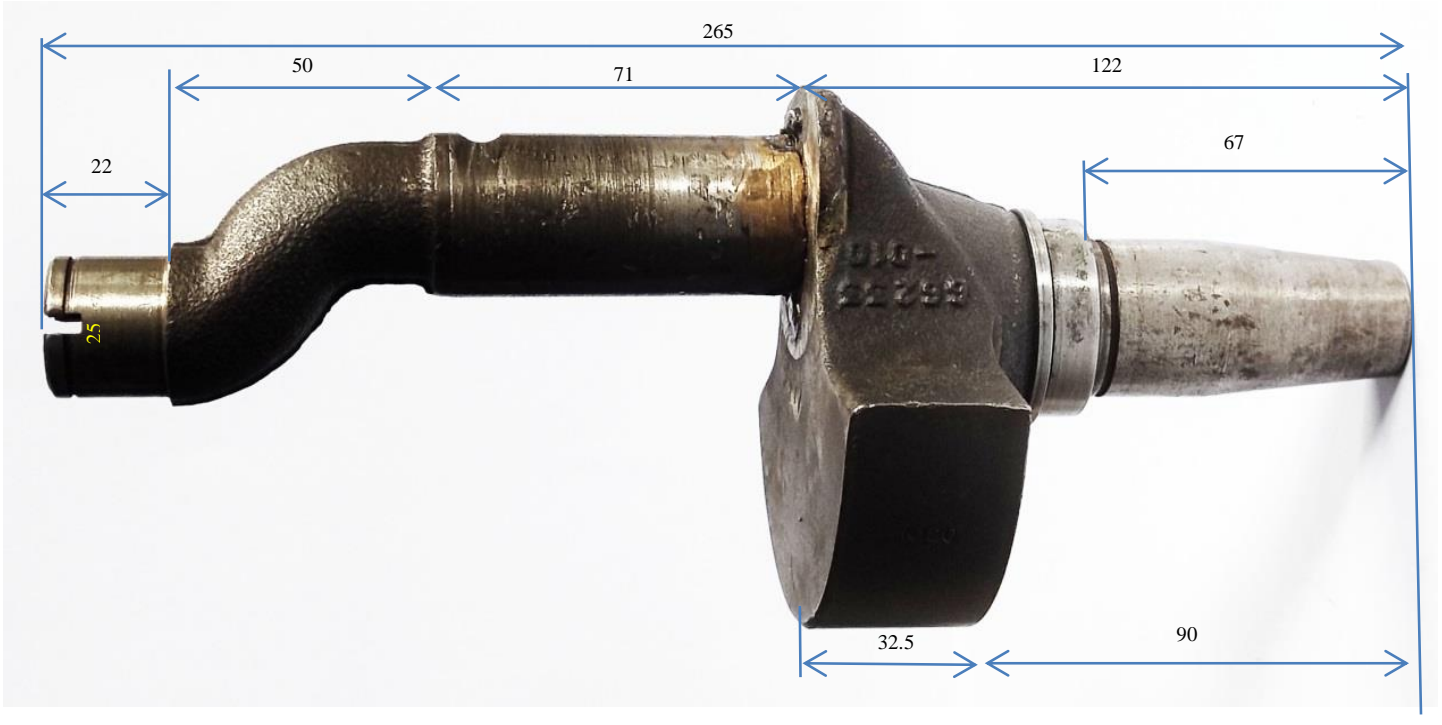

Gambar 2 a. Dimensi dan posisi awal patah 


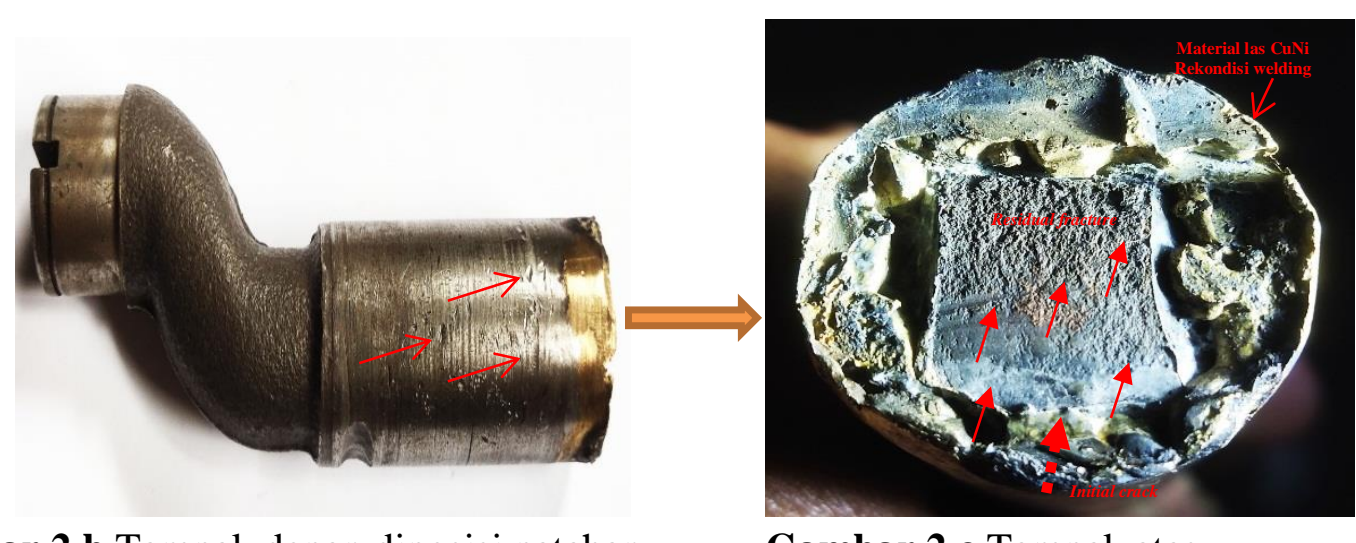

Gambar 2 b.Tampak depan diposisi patahan

Gambar 2 c.Tampak atas

Oleh sebab itu hasil dari pengamatan visual dan makro sementara disimpulkan terjadi kegagalan crankshaft pasca welding repair. Metode pengelasan kurang baik sehingga tidak mendapatkan kekuatan yang di inginkan, serta terlihat guratan pada crankshaft akibat tidak terlaksana perawatan berkala dengan baik. Sehingga faktor pendukung terjadinya kegagalan crankshaft pasca welding repair.

\section{Hasil analisis Komposisi Kimia}

Dalam penelitian ini Analisa kegagalan pasca welding repair pada crankshaft kompresor adalah jenis besi cor. Dibandingkan dengan bahan standar disajikan pada tabel 2. Dapat dilihat sebagian unsur material crankshaft yang patah sudah terpenuhi (ASM, Metal Handbook, 2005).

Tabel 2. Hasil analisis komposisi kimia material crankshaft dibandingkan dengan material standar ASM.

\begin{tabular}{|c|c|c|c|c|c|c|c|l|l|l|c|}
\hline & \multicolumn{10}{|c|}{ Komposisi \% } \\
\cline { 2 - 11 } Jenis & $\mathrm{C}$ & $\mathrm{Mn}$ & $\mathrm{Si}$ & $\mathrm{Cr}$ & $\mathrm{Ni}$ & $\mathrm{Mo}$ & $\mathrm{Cu}$ & $\mathrm{P}$ & $\mathrm{S}$ & $\mathrm{Ce}$ & $\mathrm{Mg}$ \\
\hline $\begin{array}{c}\text { Besi cor } \\
\text { nodular(ASTM) }\end{array}$ & $3,60-$ & $0,15-$ & $1,80-$ & $0,03-$ & $0,05-$ & $0,01-$ & $0,15-$ & & & $0,005-$ & $0,03-$ \\
& 3,80 & 1,00 & 2,80 & 0,07 & 0,20 & 0,10 & 1,00 & 0,03 max & $0,002 \mathrm{max}$ & 0,20 & 0,06 \\
\hline $\begin{array}{c}\text { Actual Crankshaft } \\
\text { kompresor }\end{array}$ & $>1,80$ & 0,196 & 1,56 & 0,0362 & 0,005 & 0,0217 & 0,0609 & 0,0501 & 0,0295 & $\begin{array}{c}\text { No } \\
\text { Detect }\end{array}$ & $\begin{array}{c}\text { No } \\
\text { Detect }\end{array}$ \\
\hline
\end{tabular}

Dari hasil pengujian komposisi kimia terlihat adanya perbedaan antara standard ASM dengan hasil aktual, ada beberapa faktor penyebab perbedaan hasil yaitu pada saat pengecoran kandungan komposisi sudah dibawah standard atau saat pengujian kompisisi kimia kurang akurat pembacaan mesin optical emission spectroscopy hal bisa dibuktikan melalui mikrostuktur. Karena elemen paduan seperti karbon $(C)$, silicon $(\mathrm{Si})$, Mangan $(M g)$, pospor $(P)$ dan sulfir $(S)$ sangat penting untuk kandungan pada besi cor, jika elemen paduan tidak sesuai standar maka sangat dipastikan hasil strukturmikro juga tidak sesuai spesifikasi. Akan tetepi jika hasil pengujian strukturmikro sesuai dengan spesifikasi standar kemungkinan terjadi kesalahan pembacaan pada mesin.

\section{Hasil Analisa Mikrostruktur}

Dari analisa kegagalan crankshaft untuk pengambilan sampel pengujian sama seperti pemeriksaan makrostruktur. Untuk alat mengunakan microstructure test 
performance dilakukan dengan Metallurgical Microscope Olympus GX 41 dengan pembesaran 350 kali sampai dengan 1050 kali pada objek.
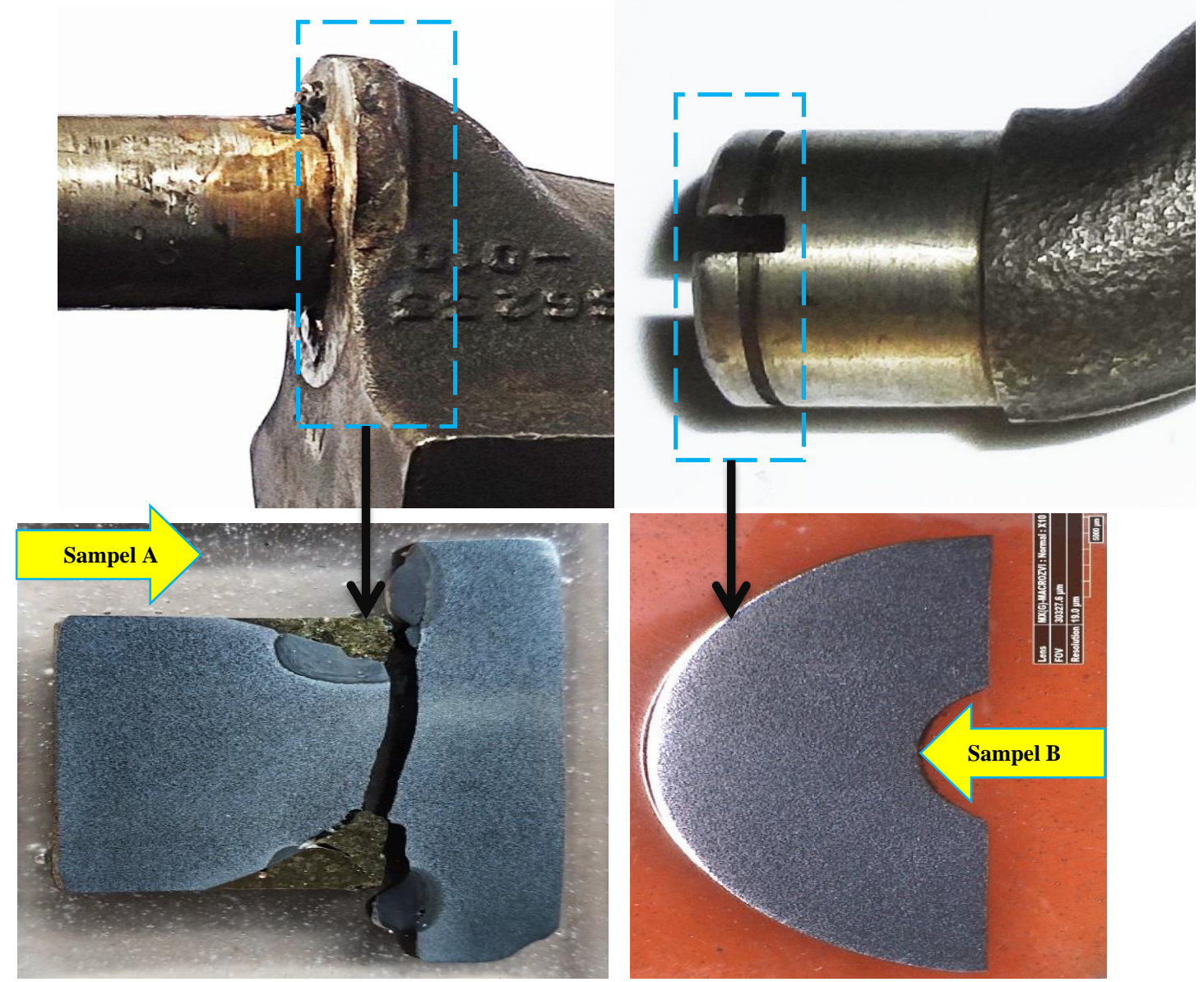

Gambar 3. Pemotongan dan pengambilan sampel untuk pengujian strukturmikro

Sejumlah potongan sampel a dan b spesimen pada (Gambar 3). Mikrostruktur yang diperoleh dari sampel a pada (Gambar 4 b) posisi disebelah kanan awal patahan (intial crack) dan (Gambar 4 a) posisi sebelah kiri akhir patahan (residual frature), terlihat bahwa pada (Gambar $4 \mathrm{c}$ dan d) parent metal atau logam induk didaerah mendekati lasan dengan (Gambar $6 \mathrm{c}$ dan d) tidak ada perbedaan sehingga logam induk yang mendekati daerah pengelasan maupun jauh dari daerah lasan tidak ada perubahan strukturmikro terdapat fase ferit, perlit dan grafit nodular serta terlihat juga pada strukturmikro besi cor nodular sudah memenuhi spesifikasi menurut (ASM Metal Handbook, 2005) tidak ada cacat terhadap proses pengecoran sehingga kegagalan yang terjadi bukan karena material yang tidak sesuai spesifikasi.

Kegagalan yang terjadi dari awal patahan (intial crack) hingga akhir patahan (residual fracture) sudah terlihat bahwa mutu pengelasan kurang baik terlihat jelas pada (Gambar 6) terdapat dua metoda pengelasan, las baja dan las $\mathrm{CuNi}$ terlihat pada strukturmikro keduanya terdapat crack terutama pada metode pengelasan oxyfuel 
welding dengan elektroda $\mathrm{CuNi}$ sangat terlihat jelas retak antar butir (intergranular cracking).

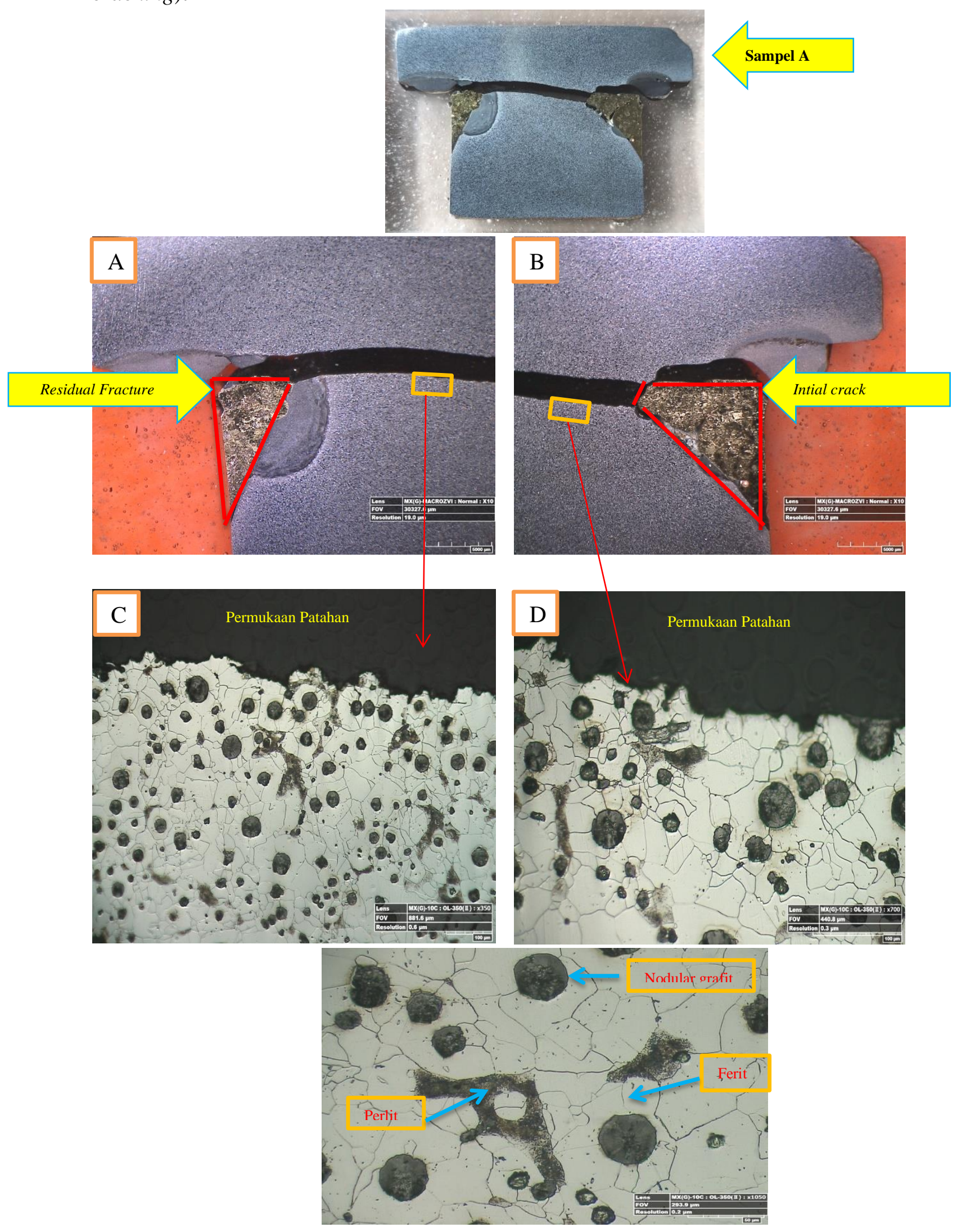


Gambar 4. Hasil pengujian microstruktur sampel A

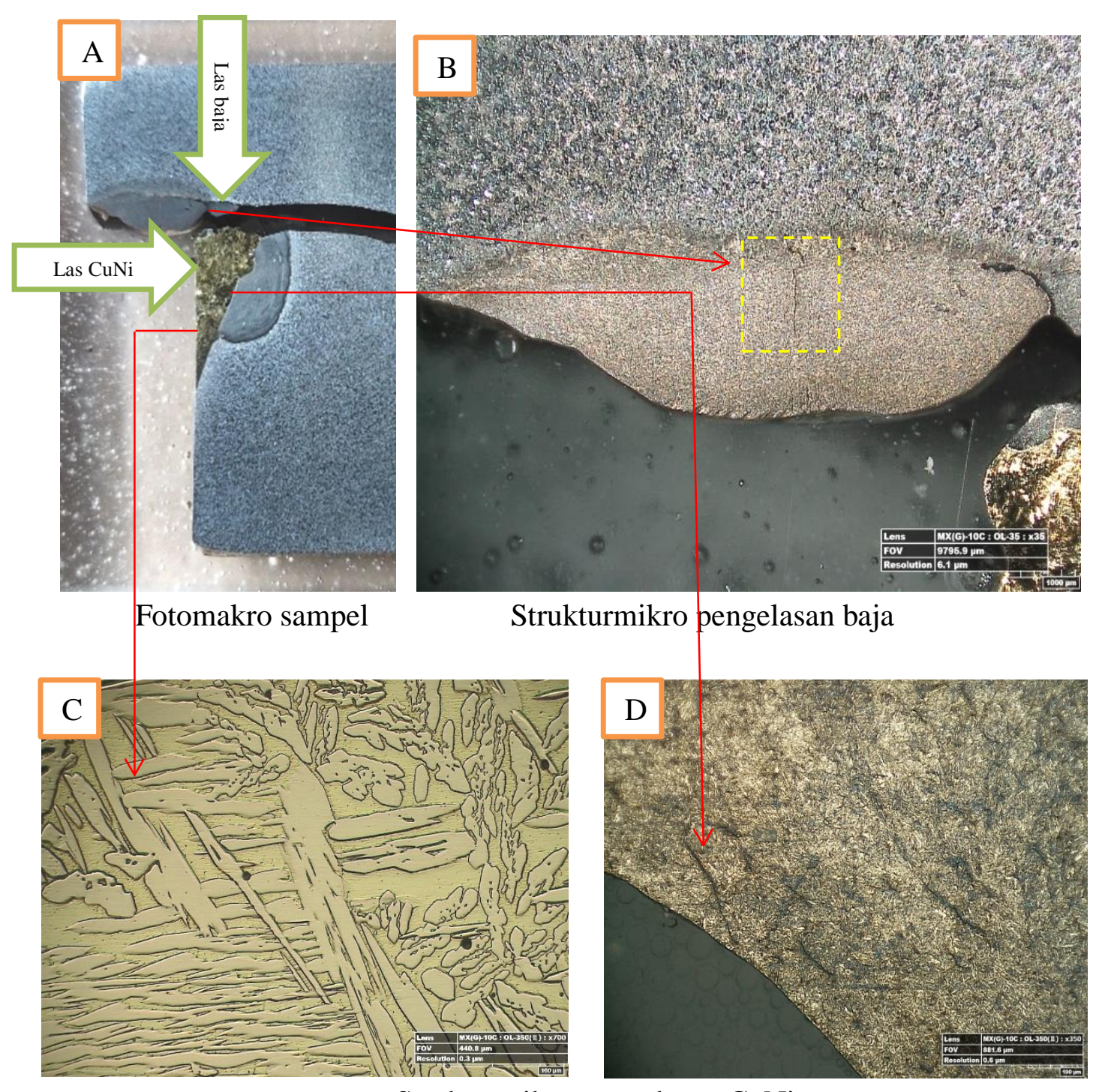

Strukturmikro pengelasan CuNi

Gambar 5. Strukturmikro daerah pengelasan baja dan $\mathrm{CuNi}$

Penyebab terjadinya retak antar butir (intergranular cracking) adalah Hot cracking terbentuk pada saat temperatur lasan yang tinggi dan biasanya berhubungan dengan solidfikasi. Hot cracking yang muncul selama pendinginan dekat dengan temperatur solidus memiliki karakterisitik intergranular cracking. Jenis dari hot cracking adalah solidification cracking, liquation cracking, ductility dip cracking dan reheat cracking. Crack biasanya timbul pada logam lasan atau HAZ base metal (Kemal Arthur Uktolseja, 2017). Penyebab terjadinya hot cracking pemelihan logam pengisi atau elektroda kurang tepat karena titik leleh besi cor nodular berbeda dengan CuNi serta tidak melakukan post weld heat treatment (PWHT) untuk mencegah terjadinya hot cracking memilih logam pengisi atau elektroda yang sesuai spesifikasi material dan melakukan perlakuan panas (PWHT) dan preheat. 


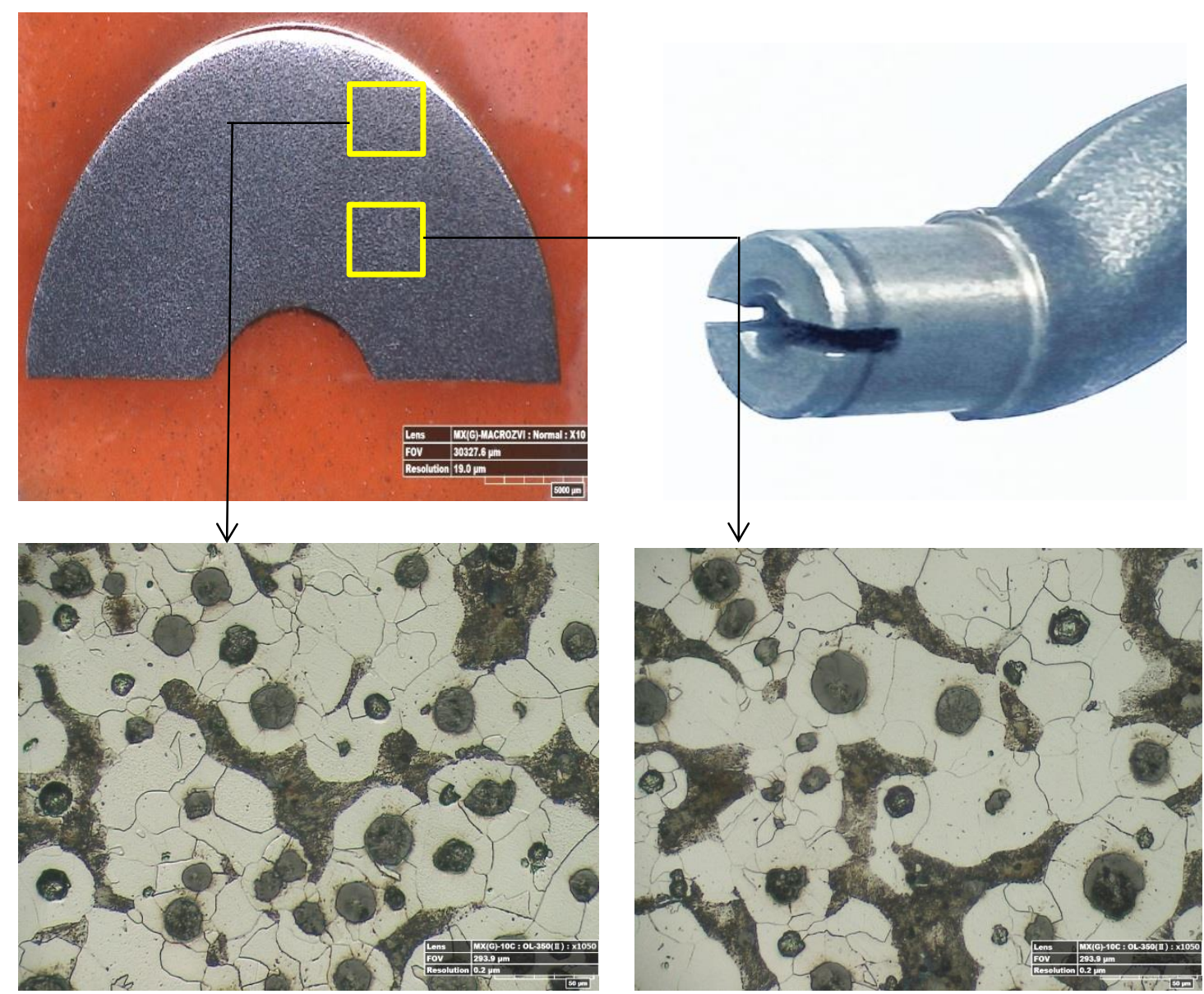

Gambar 6. Strukturmikro sampel B jauh dari daerah pengelasan dan patahan.

\section{Hasil pengujian kekerasan}

Kekerasan adalah kemampuan suatu bahan untuk menahan lekukan permanen atau deformasi ketika kontak dengan indentor di bawah beban. Umumnya tes kekerasan terdiri dari menekan indentor geometri yang diketahui dan sifat mekanik ke dalam bahan uji. Itu kekerasan material diukur dengan menggunakan salah satu dari berbagai skala yang secara langsung atau tidak langsung menunjukkan tekanan kontak yang terlibat dalam deformasi permukaan uji. Pengujian kekerasan dilakukan menggunakan metode uji kekerasan Vickers. Penetrator piramida intan dengan $\alpha=136^{\circ}$, ditekankan ke permukaan bagian yang diukur dengan beban $(\mathrm{P})=5 \mathrm{Kg}$. Pengujian kekerasan ini dilakukan secara acak pada setiap benda uji, kemudian dianalisis kekerasan pada setiap titik dan dicari nilai kekerasan rata-ratanya. 


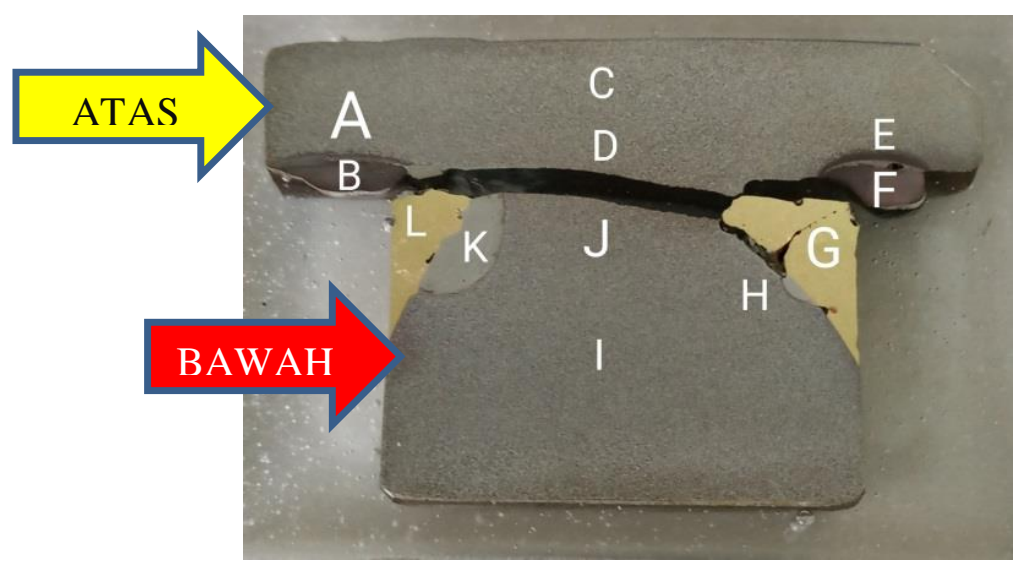

Gambar 7. Titik pengujian kekerasan dilakukan pada sampel A

Tabel 2. Nilai kekerasan daerah pengelasan area patahan

\begin{tabular}{|l|c|l|}
\hline \multirow{2}{*}{ No } & Nilai kekerasan Hardness Vickers \\
\cline { 2 - 3 } & Titik Atas & \\
\hline A & 157,3 & \\
\hline B & 682,8 & \\
\hline C & 141,8 & \\
\hline D & 160,7 & \\
\hline E & 163,3 & \\
\hline F & 671,1 & \\
\hline & Titik Bawah & \\
\hline G & 144,3 & \\
\hline H & 168,3 & \\
\hline I & 161,9 & \\
\hline J & 159,6 & \\
\hline K & 164,1 & \\
\hline L & 115,7 & \\
\hline
\end{tabular}

Dari hasil pengujian kekerasan pada (tabel 2) nilai tertinggi pada titik b dengan nilai 682,8 HV terlihat kekerasan tertinggi pada daerah pengelasan dengan bahan baja karbon terlihat strukturmikronya fase yang terjadi adalah martensit. Dan nilai terendah pada daerah pengelasan $O F W$ dengan material $\mathrm{CuNi}$ yaitu nilainya $115,7 \mathrm{HV}$, logam induk atau material crankshaft kompresor nilai kekerasannya $161 \mathrm{HV}$. Material crankshaft kompresor dengan jenis besi cor nodular menurut ASM metal handbook dikatergorikan SAE J434 nilai kekerasannya 164 - 268 HV[5].

\section{Kesimpulan}

Setelah melakukan analisa dilapangan, wawancara dengan maker machine serta sudah dilakukan pengujian di laboratorium maka dapat disimpulkan hasilnya sebagai berikut:

1. Berdasarkan hasil pengamatan dilapangan kompresor telah terjadi kegagalan 
pertama 19 Mei 2019 dengan jam operasi 3298 jam jika digunakan perharinya \pm 5 jam. Dikarenakan dengan adanya kebutuhan produksi urgent maka dari itu dilakukan repair dengan dua metode pengelasan Oxyfuel gas welding (OFW ) material $\mathrm{CuNi}$ dan las listrik dengan material baja karbon, dikarenakan logam pengisi tidak homogen dengan material crankshaft kompresor ketika dipasang kembali dan di coba untuk beroperasi kurang dari 1 menit crankshaft kompresor patah kembali.

2. Hasil pengujian komposisi kimia untuk material crankshaft kompresor yaitu besi cor nodular SAE J434 (ductile iron) mikrostruktur feritic dengan kandungan karbon (C) lebih dari 1,80 \%, silikon (Si) 1,56 \%, Mangan (Mn) 0,196 \% pada besi cor SAE J434 memerlukan tindakan khusus sebelum dilakukan pengelasan atau sesudah pengelasan dengan tujuan untuk menghidari pembentukan sementit yang membuat daerah yang dilas menjadi rapuh dan juga untuk mempertahankan bentuk grafit nodular (ASM Metal Handbook, 2005).

3. Pengamatan visual dan makro terhadap permukaan lokasi awal patah pada kompresor crankshaft berasal dari bawah (intial frature) sudut tegak lurus terhadap poros ØD $30 \mathrm{~mm}$ dengan beban penyeimbang (Gambar $2 \mathrm{~b}$ ) dan dilihat dari permukaan poros tersebut banyak ditemukan cacat guratan melingkar akibat gesekan dengan bearing sehingga putaran crankshaft tidak normal, dengan adanya cacat permukaan pada poros tersebut diduga pelumasan tidak normal atau kondisi pelumas kotor, sehingga putaran atau bekerjanya piston terganggu. Permukaan patahan crankshaft pasca welding repair mempunyai bentuk patah getas karena terlihat pada (gambar 2c) terdapat cacat pengelasan yang bergelombang, berongga penyebabnya saat pengelasan tidak dibersihkan atau diratakan terlebih dahulu, kurangnya pengalaman operator las sehingga hasilnya buruk serta berpengaruh logam pengisi CuNi karena tidak homogen dengan material crankshaft sehingga hal itu yang menyebabkan patah getas.

4. Patahnya crankshaft pasca welding repair mengalami solidification cracking (hot cracking) yang disebabkan kesalahan pemilihan logam pengisi lasan, tidak melakukan PWHT dan preheat, serta faktor pendukung terlalu banyak kandungan karbon.

5. Pengujian mikrohardness menunjukan daerah pengelasan memiliki angka kekerasan Vickers $(682,8$ HVN dan 671,1 HVN) karena struktur yang dihasilkan adalah sementit pada daerah lasan logam pengisi baja karbon yang jauh lebih besar dibangingkan daerah lainnya. Nilai terendah daerah lasan CuNi 115,7 HVN penyebabnya spesifikasi kekerasan material $\mathrm{CuNi}$ lebih rendah di banding besi cor nodular hanya 59,47 VHN (Yosep Reza Budi Setiawan, 2018).

6. Dari hasil pengamatan visual dan data dilapangan bahwa crankshaft kompresor untuk jadwal perawatan berkala dari harian, bulanan dan harian tidak terlaksana dengan baik sehingga menyebabkan kegagalan pada crankshaft jika terjadi dalam jangka waktu yang lama dan terus menerus dapat mengurangi umur pakai kompresor. 
7. Pengambilan sampel pemeriksaan strukturmikro patahan crankshaft pasca welding repair diambil pada potongan memanjang shaft dan dibagian normal sebagai perbandingan, menggunakan etsa Nital $2 \%$ dan $\mathrm{K}_{2} \mathrm{Cr}_{2} \mathrm{O}_{7}$. Pada (tabel 2) pengujian komposisi kimia terlihat adanya perbedaan antara standar dengan aktual hal ini bisa dilihat dengan hasil strukturmikro material crankshaft berupa besi cor kelabu dan struktur mikro berupa ferit (putih) dan perlit (hitam) dengan grafit bulat (Nodular graphyte) strukturmikro besi cor nodular sudah sesuai dengan standar. Akan tetapi adanya cacat pada proses pengelasan, pengelasan $\mathrm{CuNi}$ dan pengelasan las lisrtik baja karbon terlihat adanya retak atau crack intergranular yang menyebabkan kekuatan tidak maksimal, penyebab adanya crack intergranular pada saat proses pengelasan terdapat solidification cracking karena salahnya pemelihan logam pegisi dan tidak adanya PWHT sehingga menyebabkan daerah lasan mengalami solidification cracking terjadi dibeberapa titik sehingga kekuatan lasan lemah karena banyak cacat. 


\section{Bibliography}

ADNYANA, D. N. (n.d.). Data Thesis 2020-2021.

ASM Metal Handbook Vol. 06 Welding, Brazing and Soldering, 1993

Asyari, D. (n.d.). Analisis Kerusakan Pada Poros Penghubung Kompresor Torak. Jurnal Sains \& Teknologi Fakultas Teknik, 1(2), 39-45.

Bloch, H. P., \& Geitner, F. K. (1999). Machinery Failure Analysis and Troubleshooting, Vol. 2. Gulf Publishing Co.

Febriyanti, E., \& Suhadi, A. (2016). ANALISIS KEGAGALAN FIRE RING PENYEBAB KERUSAKAN PISTON MESIN UNIT KENDARAAN BERMOTOR. Majalah Ilmiah Pengkajian Industri, 10(2), 99-106.

GmBH, B. K. (2010). Operating Manual High pressure Compressor for Breathing Air.

Ibad, I. K., \& Rochiem, R. (2014). Analisa kegagalan baut piston VVCP gas kompresor gemini DS-504 EMP Malacca Strait SA. Jurnal Teknik ITS, 3(2), F180-F184.

Jones, D. R. H. (2013). Failure analysis case studies II. Elsevier.

Layer, J., Adler, T., \& Ahmed, R. (2018). ASM Handbook Volume 11 Failure Analysis and Prevention. ASM International.

Murti, F. N., \& Nurhasanah, N. (2019). Analisa Risiko Kegagalan Kompresor K-3-02 B di Plant $3 C$ PT. Pertamina (Persero) RU V Balikpapan menggunakan Failure Mode and Effect Analysis (FMEA) dan Fault Tree Analysis (FTA).

Qosim, N. (2017). THE ANALYSIS OF RECIPROCATING COMPRESSOR PK 60150 FAILURE USING FAILURE MODE AND EFFECT ANALYSIS METHOD. Jurnal Penelitian Saintek, 22(2), 80-89.

Steels, H.-S. L.-A. (2005). ASM handbook, volume 1, properties and selection: irons, steels, and high performance alloys section: carbon and low-alloy steels.

Bauer Germany. (2017) Handbook manual compressor Hal. 20.

R. Bagus Suryayasa Majanasastra, (2016) ANALISIS SIFAT MEKANIK DAN STRUKTUR MIKRO HASIL PROSES HYDROFORMING PADA MATERIAL TEMBAGA $(\mathrm{Cu})$ DAN ALUMUNIUM Al 6063.

Kemal Arthur Uktolseja, Margono Sugeng (2017) ANALISA KERUSAKAN SAMBUNGAN LASAN PADA SISTEM VENTING PRE AIR COOLER DILINGKUNGAN EKSPLORASI DAN PRODUKSI GAS ALAM. 